\title{
Sertifikasi Halal Sebagai Strategi Dakwah MUI (Majelis Ulama Indonesia) Jawa Tengah
}

\author{
Asri Wahyuningrum, Anasom, Thohir Yuli Kusmanto \\ Yayasan Nur Rochman Cikarang Jawa Barat
}

Email: asri_22@rocketmail.com; anas_jauhar4@gmail.com; thohiryuli@yahoo.co.id

\begin{abstract}
This research aim is determine the certification of halal as a da'wa strategies of MUI Central Java and also supporting and inhibiting factors there. This Research used qualitative research using management of da'wa approach. The data were collected through techniques: interview, observation, and documentation. The data analysis are data: reduction, verification, and conclusion. The result of this research: there are two da'wa strategies used LPPOM MUI which on program Gerakan Masyarakat Sadar Halal "GEMAR HALAL", that became a certificationstrategy and the socialization and promotion strategies. The supporting factors are the availability of facilities and infrastructure, the cooperation of internal and external institution, the participation of community on the program, and members who competence and experience on their fields. Whereas inhibiting factors are some members who have double positions on one institution, lack of funds, and member's lack of discipline on their work.
\end{abstract}

Penelitian ini bertujuan untuk mengetahui sertifikasi halal sebagai strategi dakwah MUI Jawa Tengah serta faktor pendukung dan penghambatnya. Peneliti menggunakan penelitian kualitatif dengan pendekatan manajemen dakwah. Teknik pengumpulan datanya melalui wawancara, observasi, dan dokumentasi. Teknik analisis datanya yaitu reduksi data, penyajian data, dan penarikan kesimpulan. Hasil penelitian ini menunjukkan bahwa: ada dua strategi dakwah yang digunakan LPPOM MUI yang terdapat dalam program Gerakan Masyarakat Sadar Halal "Gemar HALAL", yaitu strategi pensertifikasian dan strategi sosialisasi dan promosi. Faktor pendukung diantaranya tersedianya sarana dan prasarana yang memadai, terjalinya kerjasama dengan pihak internal dan eksternal lembaga, keikutsertaan umat dalam program, dan anggota yang berkompeten dan berpengalaman sesuai bidangnya. Sedangkan faktor penghambatnya yaitu ada beberapa anggota yang mempunyai rangkap jabatan dalam satu lembaga, minimnya dana, dan kurang disiplinnya anggota akan pekerjaan yang menjadi tanggung jawabnya.

Keywords: certification of halal, da'wa strategies, MUI Central Java 


\section{A. Pendahuluan}

Kebutuhan konsumsi makanan dan minuman bukanlah semata-mata hanya pemenuhan hidup, tetapi lebih dari itu pemenuhan gizi yang memiliki standard kesehatan bagi manusia itu sendiri. ${ }^{1}$ Masalah pangan berkaitan erat dengan kehidupan dan keutuhan bangsa, maka perlu ada pengaturan, pembinaan dan pengawasan terhadap pangan khususnya oleh Negara. ${ }^{2}$

Masalah-masalah klasik mutu pangan selalu saja dihubungkan dengan sisi kesehatan dan persoalan halal. Kedua masalah ini selalu mencuat dan khusus untuk jaminan halal selalu berdampak terhadap kehidupan bernegara. Masalahnya banyak kalangan di Indonesia yang hanya memandang jaminan halal dalam kacamata ajaran Islam dan tata nilai religi belaka. Bukan dilihat dari sisi ekonomi, politik dan bisnis yang berpengaruh didalamnya. Pembuatan standard jaminan halal akan memberikan banyak manfaat bagi Negara, bangsa, dan konsumen. Bagi Negara jelas pembuatan jaminan halal berarti pemasukan kas Negara yang tergolong tarif bukan pajak. Sedangkan dari sisi politik jelas pembuatan standardisasi jaminan halal akan memperkuat posisi Negara terhadap klaim mutu produk barang pangan dalam negeri kepada pasar dunia. ${ }^{3}$

Di sisi yang lain, urusan halal dan haram sesungguhnya berputar pada edar syariat Islam secara umum. ${ }^{4} \mathrm{Hal}$ ini sesuai dengan kebijakan pemerintah lewat peraturan pemerintah No. 69 tahun 1999 yang menyebutkan, bahwa pangan halal adalah pangan yang tidak mengandung unsur atau bahan yang haram atau dilarang untuk dikonsumsi umat Islam, baik yang menyangkut bahan baku pangan, bahan tambahan pangan, bahan bantu dan bahan penolong lainnya termasuk bahan pangan yang diolah melalui proses rekayasa genetika dan iradikasi pangan, dan yang pengolahannya dilakukan sesuai dengan ketentuan hukum agama Islam ${ }^{5}$

Dalam UU Republik Indonesia Nomor 33 tahun 2014 tentang Jaminan Produk Halal pada pasal 3 menyebutkan bahwa semua produk yang masuk,

1 Bagian Proyek Pembinaan Pangan Halal Direktorat Jenderal Bimbingan Masyarakat dan Penyelenggaraan Haji, Buku Pedoman Strategi Kampanye Sosial Produk Halal, (Jakarta: Departemen Agama RI, 2003), hlm.1.

2Ibid., hlm.3.

3Ibid., hlm.4.

4 Yusuf Qardhawi, Halal Haram Dalam Islam, (Solo: PT Era Adicitra Intermedia, 2011), hlm.17.

5 Bagian Proyek Pembinaan Pangan Halal Direktorat Jenderal Bimbingan Masyarakat Dan Penyelenggaraan Haji, Op.Cit.,Buku Pedoman Strategi Kampanye Sosial Produk Halal, hlm.6. 
beredar, dan diperdagangkan di wilayah Indonesia wajib bersertifikat halal. Namun, pada kenyataanya produk yang beredar di masyarakat belum semua terjamin kehalalannya. Halal bukan hanya sertifikasi, itu hanya bagian terkecilnya saja. Halal juga tentang bagaimana prosesnya dapat menjamin kehalalan industri tersebut. Industri makanan dan minuman menempati peranan yang sangat penting, dan sebagian besar adalah industri kecil dan rumah tangga. ${ }^{6}$

Memproduksi produk halal adalah bagian dari tanggungjawab perusahaan kepada konsumen muslim. Di Indonesia, untuk memberikan keyakinan kepada konsumen bahwa produk yang dikonsumsi adalah halal, maka perusahaan perlu memiliki Sertifikat Halal MUI. ${ }^{7}$

Masyarakat sebagai konsumen lebih mempercayakan sepenuhnya pengawasan jaminan produk halal kepada Negara yang mereka anggap paling berwenang memberikan sanksi dan tekanan hukum bila dianggap perlu. ${ }^{8}$ Standar jaminan halal merupakan bentuk klaim bahwa produknya yang halal dapat dikategorikan sebagai produk yang bermutu dan higienis. ${ }^{9}$

Pada dasarnya keberadaan jaminan produk halal berangkat dari pertimbangan konsep luhur, bahwa masyarakat berhak mendapatkan informasi yang benar, jelas dan lengkap baik secara kuantitas maupun kualitas dari produk yang mereka konsumsi. Dengan demikian praktekpraktek kadaluarsa, pemakaian bahan pewarna yang tidak diperuntukkan dan bahan-bahan berbahaya lainnya serta perbuatan-perbuatan lain yang mengakibatkan kerugian masyarakat, bahkan mengancam jiwa, keselamatan dan kesehatan dapat terhindari. ${ }^{10}$

Setiap manusia pun mempunyai kewajiban mengkonsumsi pangan yang halal dan thayyib sesuai dengan firman Allah SWT dalam Q.S. AlBaqarah: 168.

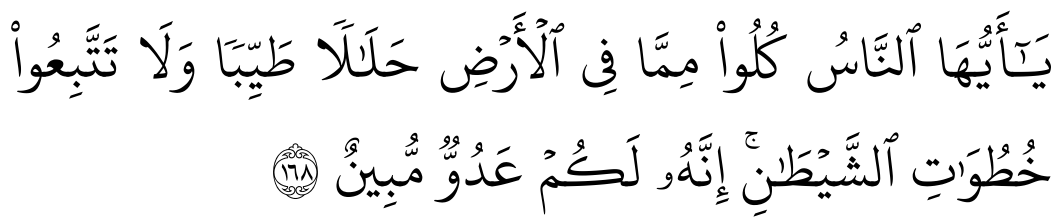

6Undang-Undang Republik Indonesia Nomor 33 tahun 2014 tentang Jaminan Produk Halal pada pasal 3 .

7 Lembaga Pengkajian Pangan Obat-Obatan dan Kosmetika Majelis Ulama Indonesia, Panduan Umum System Jaminan Halal LPPOM-MUI, (Jakarta: LPPOM MUI, 2008), hlm. 7.

${ }^{8}$ Bagian Proyek Pembinaan Pangan Halal Direktorat Jenderal Bimbingan Masyarakat Dan Penyelenggaraan Haji, Op.Cit., hlm. 3.

9 Ibid., hlm. 4.

10Ibid., hlm. 5. 
Hai sekalian manusia, makanlah yang halal lagi baik dari apa yang terdapat di bumi, dan janganlah kamu mengikuti langkah-langkah syaitan; karena Sesungguhnya syaitan itu adalah musuh yang nyata bagimu.

Ayat tersebut dengan jelas memberikan tekanan pada pentingnya manusia mengkonsumsi makanan yang halal dan thayyib (bergizi). Yang selanjutnya ada peringatan agar manusia tidak mengikuti jejak setan yang sudah dipastikan akan menjuruskan pada lembah kesesatan.

Makanan yang disebut ayat tersebut menyiratkan sebuah makna akan pentingnya semangat spritualisme dalam memperoleh dan mengkonsumsi makanan. Bahaya mengonsumsi produk haram bagi kaum muslimin antara lain: pertama, ibadah tertolak. Doa adalah ibadah. Makanan haram membuat doa-doa menjadi terhalang dan tidak dikabulkan Allah SWT. Iman Ibn Katsir rahimahullah berkata: "Mengonsumsi produk yang halal adalah faktor diterimanya sebuah doa atau ibadah, sebagaimana mengonsumsi produk yang haram dapat menghalangi diterimanya doa atau ibadah tersebut". Kedua, masuk neraka. Dalam salah satu hadits, Rasulullah SAW bersabda: "Tidak masuk surga daging dandarah yang tumbuh dari makanan yang haram, karena neraka lebih pantas baginya". Tubuh jika diberi asupan makanan yang haram maka akan enggan untuk beribadah dan taat kepada Allah SWT, tapi justru akan gemar melakukan perbuatan maksiat. Ketiga, membahayakan tubuh. Allah SWT menghalalkan hal-hal yang baik karena ada hikmah didalamnya. Begitu pula Allah SWT mengharamkan hal-hal yang buruk karena berbahaya bagi tubuh kita. Salah satu hikmah menghindari makanan yang haram adalah terhindarnya diri kita dari penyakit.11

Jadi, halalnya pangan dapat kita mengerti sebagai suatu masalah yang sangat pokok dan fundamental untuk kehidupan, agama dan keberlangsungan hidup umat Islam. Selain itu juga dampak secara langsung dari mengkonsumsi makanan halal terhadap perilaku yaitu:

Pertama, menjaga keseimbangan jiwa manusia yang hakikatnya suci sebagaimana baru dilahirkan di dunia. Perintah untuk selalu menjaga kehalalan makanan seiring dengan amal sholeh yang akan dilakukan untuk menjaga keseimbangan fitrah manusia seiring dengan maksud ayat:

11 Lembaga Pengkajian Pangan Obat-Obatan dan Kosmetika Majelis Ulama Indonesia, Buku Panduan Olimpiade Halal LPPOM MUI, 2014, hlm. 2 


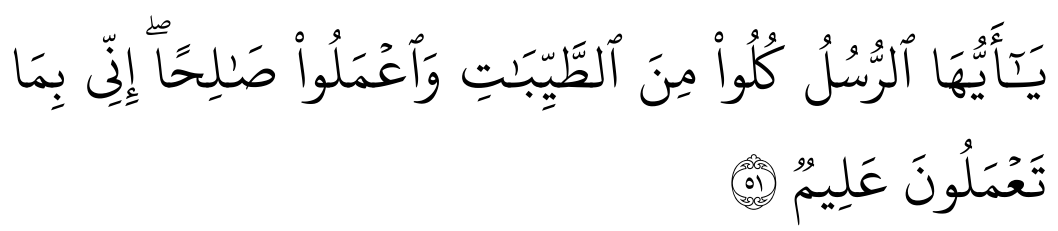

Hai rasul-rasul, makanlah dari makanan yang baik-baik, dan kerjakanlah amal yang saleh. Sesungguhnya aku Maha mengetahui apa yang kamu kerjakan. (Q.S. Al Mukminun: 51)

Kedua, menumbuhkan sikap juang yang tinggi dalam menegakkan ajaran Allah dan Rasul-Nya di bumi. Bagi orang yang selalu mengusahakan untuk menjaga makanannya dari yang haram berarti ia telah berjuang dijalan Allah dengan derajat yang tinggi.

Ketiga, dapat membersihkan hati dan menjaga lisan dari pembicaraan yang tidak perlu. Makanan halal yang dikonsumsi akan tumbuh dan berkembang menjadi daging bersamaan dengan meningkatnya kualitas kesalehan baik lahir dan batin.

Keempat, menumbuhkan kepercayaan diri dihadapan Allah. Orang yang selalu mengkonsumsi makanan halal, maka dengan sendirinya akan menambah keyakinan diri bahwa Allah dekat dengan kita yang selalu memdengarkan permintaan doa kita. ${ }^{12}$

Berdasarkan data di LP POM MUI Jawa Tengah, produk-produk yang telah bersertifikat halal periode Maret 2014 - Maret 2016 sebanyak 584 produk, meliputi berbagai produk makanan, minuman, obat-obatan dan kosmetik. ${ }^{13}$ Jumlah ini tentu berbeda dengan produk makanan, minuman, obat-obatan dan kosmetik yang beredar di masyarakat yang begitu banyaknya. Sehingga membutuhkan kehati-hatian dalam mengkonsumsi aneka ragam produk yang tersebar di masyarakat.

Apalagi dengan teknologi modern, yang haram-haram justru banyak digunakan yang jejak penggunaannya pun sulit terdeteksi, sehingga diperlukan adanya suatu jaminan dan kepastian akan kehalalan produkproduk pangan yang dikonsumsi umat Islam yang merupakan bagian terbesar penduduk Indonesia.

12Thobieb Al- Asyhar, Bahaya Makanan Haram Bagi Kesehatan Jasmani dan Kesucian Rohani, (Jakarta: PT Al-Mawardi Prima, 2003) hlm. 83-86.

${ }^{13}$ LPPOM MUI Jawa Tengah, Daftar Produk Bersertifikat Halal Periode Maret 20142016. 
Jaminan kehalalan suatu produk pangan dapat diwujudkan diantaranya dalam bentuk sertifikat halal yang menyertai suatu produk pangan, yang dengan sertifikat halal produsen dapat mencantumkan logo halal pada kemasanya. ${ }^{14}$

Di sinilah suatu produk perlu mendapatkan sertifikat halal. Sertifikasi halal dapat dijadikan sebagai alat strategi dakwah untuk memberikan edukasi kepada masyarakat dan juga anjuran untuk mengkonsumsi pangan halal. Bentuk edukasi dan penyadaran kepada masyarakat baik itu dari sisi produsen untuk selalu menyadari pentingnya memproduksi produk halal dan sisi konsumen yaitu dengan mengajak umat untuk lebih berhati-hati dalam mengkonsumsi produk-produk pangan yang akan di konsumsi.

Dengan situasi dan kondisi masyarakat yang sekarang ini perlu waspada dalam mengkonsumsi produk pangan, obat-obatan ataupun kosmetik. Sudah sering kali ditemukan kecurangan-kecurangan dalam proses pengolahan, penyimpanan bahkan pendistribusian tak jarang bercampur dengan barang yang haram yang jelas dilarang syariat Islam dalam mengkomsumsinya.

Usaha dalam berdakwah ditengah-tengah kebutuhan manusia merupakan usaha dakwah yang harus dilaksanakan oleh umat Islam, baik secara individu maupun kelompok. Perintah ini telah ditegaskan dalam Q.S. Ali Imron: 104.

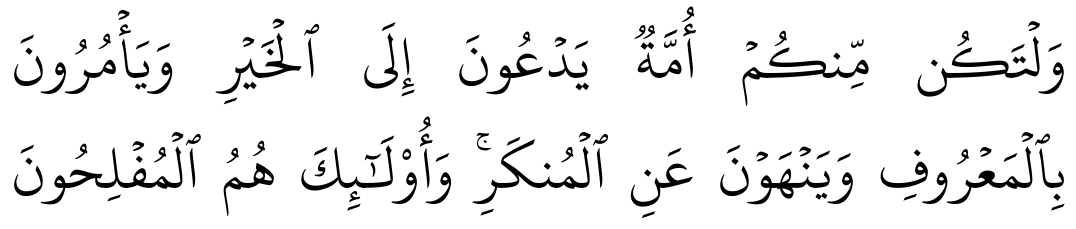

Dan hendaklah ada di antara kamu segolongan umat yang menyeru kepada kebajikan, menyuruh kepada yang ma'ruf dan mencegah dari yang munkar, merekalah orang-orang yang beruntung.

Berlandaskan ayat tersebut dan melihat realita masyarakat sekarang ini, maka dalam berdakwah membutuhkan adanya inovasi dan strategi.

14 Anton Apriyantonodan Nurbowo, Panduan Belanja dan Konsumsi Halal, (Jakarta: Khairul Bayan, 2003), hlm. 24. 
Sehingga Islam dapat masuk di setiap lini kehidupan dan dapat diterima sesuai dengan perkembangan keilmuan dan teknologi.

Dalam upaya menentramkan umat Islam dalam masalah kehalalan produk pangan, MUI mendirikan Lembaga Pengkajian Pangan, Obat-obatan dan Kosmetika MUI (LP POM) yang bertugas untuk melakukan pengkajian kehalalan produk pangan, obat dan kosmetika. Sebagai upaya untuk memberi kepastian mengenai kehalalan produk pangan maka LP POM MUI mulai melakukan kegiatan sertifikasi halal bagi produk pangan. ${ }^{15}$

Dalam mendapatkan Sertifikat halal terdapat suatu sistem manajemen proses yang dilakukan oleh MUI terhadap perusahaan yang mengajukan sertifikasi halal. Manajemen menaruh perhatian pada penyelesaian kegiatan-kegiatan agar sasaran organisasi tercapai.

Berdasarkan uraian di atas, penulis tertarik untuk mengkaji lebih lanjut dengan melakukan penelitian yang berjudul "Sertifikasi Halal Sebagai Strategi Dakwah Majelis Ulama Indonesia Jawa Tengah". Dalam penelitian ini dibahas beberapa masalah yaitu: 1) Bagaimana sertifikasi halal sebagai strategi dakwah Majelis Ulama Indonesia Jawa Tengah? 2) Apa saja faktor pendukung dan penghambat sertifikasi halal sebagai strategi dakwah Majelis Ulama Indonesia Jawa Tengah?

\section{B. Kerangka Konseptual}

\section{Sertifikasi Halal}

\section{a. Pengertian Sertifikasi}

Sertifikasi dapat diartikan sebagai syarat-syarat yang harus dipenuhi dalam proses pengawasan mutu pangan yang penyelenggaraannya dapat dilakukan secara laboratories atau cara lain sesuai dengan perkembangan teknologi. Sertifikasi mutu ini diberlakukan guna memberikan jaminan kepada masyarakat, bahwa pangan yang dibeli telah memenuhi standard mutu tertentu, tanpa mengurangi tanggung jawab pihak produsen pangan guna memenuhi ketentuan kebijakan hukum yang ada. ${ }^{16}$

\section{b. Pengertian Halal}

15Ibid., hlm. 25.

16Bagian Proyek Pembinaan Pangan Halal Direktorat Jenderal Bimbingan Masyarakat Dan Penyelenggaraan Haji, Buku Pedoman Strategi Kampanye Sosial Produk Halal, (Jakarta: Departemen Agama RI, 2003), hlm. 8-9. 
Kata halal berarti diperbolehkan (oleh hukum Islam), tidak haram. ${ }^{17}$ Halal berasal dari bahasa Arab halla yang artinya "lepas" atau "tidak terikat". Secara etimologi kata halalan berati hal-hal yang boleh dan dapat dilakukan karena bebas atau tidak terikat dengan ketentuan-ketentuan yang melarangnya, atau segala sesuatu yang bebas dari bahaya duniawi dan ukhrawi. ${ }^{18}$

Pada dasarnya segala sesuatu yang diciptakan Allah SWT itu halal. Tidak ada yang haram kecuali jika ada nash (dalil) yang shahih (tidak cacat periwayatannya) dan sharih (jelas maknanya) dari pemilik syariat (Allah SWT) yang mengharamkannya. Perintah mengkonsumsi makanan halal dapat disejajarkan dengan bertaqwa kepada Allah SWT, dan secara tegas dan jelas termaktub dalam firman Allah Q.S. Al Maidah: 88 yaitu19: "Dan makanlah makanan yang halal lagi baik dari apa yang Allah telah rezekikan kepadamu, dan bertakwalah kepada Allah yang kamu beriman kepadaNya."

Dalam Sebuah Hadist Nabi, kategori makanan dibagi menjadi tiga macam, yaitu: ${ }^{20}$

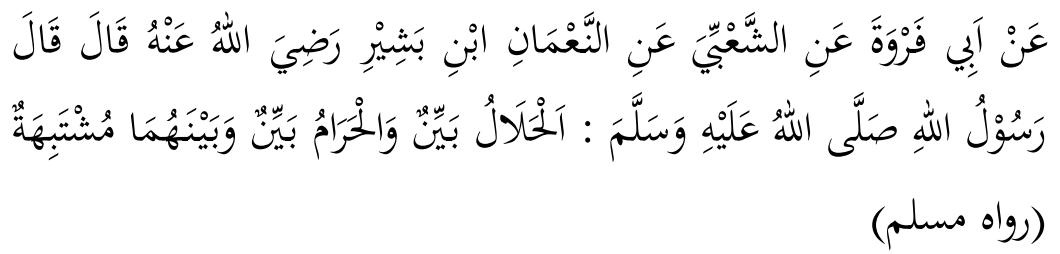

Dari Abi Farwah dari Sya'bi dari Nu'man ibnu Basyir r.a berkata, bersabda Rasulullah SAW: Sesungguhnya halal itu jelas an haram pun jelas. Dan diantara keduanya ada hal-hal yang samara atau tidak jelas. (HR Muslim).

Produk halal menurut definisi Lembaga Pengkajian Pangan, Obatobatan, dan Kosmetika Majelis Ulama Indonesia (LPPOM-MUI) adalah produk yang memenuhi syarat kehalalan sesuai syari'at Islam. Produk tidak mengandung babi atau produk-produk yang berasal dari babi, serta tidak mengandung alkohol sebagai ingredient yang sengaja ditambahkan.

${ }^{17}$ Achmad Maulana, dkk, Kamus Ilmiah Populer: Lengkap dengan EYD dan Pembentukan Istilah serta Akronim Bahasa Indonesi,(Yogyakarta: Absolut, 2008), hlm.187.

18 Lembaga Pengkajian Pangan Obat-Obatan dan Kosmetika Majelis Ulama Indonesia, Buku Panduan Olimpiade Halal LPPOM MUI, 2014, hlm. 5.

${ }^{19}$ Ibid. hlm. 6.

20Thobieb Al-Asyhar, Bahaya Makanan Haram bagi kesehatan Jasmani dan Kesucian rohani, (Jakarta: PT. Al-Mawardi Prima, 2003), hlm. 91. 
Untuk daging sebagai bahan baku, harus berasal dari hewan halal yang disembelih menurut tata cara syariat Islam ${ }^{21}$

\section{c. Pengertian Sertifikasi Halal}

Sertifikasi Halal adalah suatu proses untuk memperoleh sertifikat halal melalui beberapa tahap untuk membuktikan bahwa bahan, proses produksi dan Sistem Jaminan Halal memenuhi standar LPPOM MUI. Sedangkan Sertifikat Halal adalah fatwa tertulis yang dikeluarkan oleh MUI yang menyatakan kehalalan suatu produk yang merupakan keputusan sidang Komisi Fatwa MUI berdasarkan proses audit yang dilakukan oleh LPPOM MUI. ${ }^{22}$ Sertifikat halal MUI ini merupakan syarat untuk mendapatkan ijin pencantuman label halal pada kemasan produk dari instansi pemerintah yang berwenang. ${ }^{23}$

Tujuan Sertifikasi Halal pada produk pangan, obat-obat, kosmetika dan produk lainnya dilakukan untuk memberikan kepastian status kehalalan, sehingga dapat menentramkan batin masyarakat dalam mengkonsumsi makanan sesuai dengan imannya, sehingga dapat menunjang kelancaran dan kestabilan pembangunan nasional. Kesinambungan proses produksi halal dijamin oleh produsen dengan cara menerapkan Sistem Jaminan Halal. Demikian juga dengan adanya sertifikasi halal membuat produsen makanan tidak akan dirugikan, justru akan lebih terjamin kelangsungan usahanya. ${ }^{24}$

\section{Strategi Dakwah}

\section{a. Pengertian Strategi}

Strategi berasal dari bahasa Yunani kuno "strategos" (strato, berarti tentara dan ego yang berarti pimpinan) yang berarti "seni berperang". Suatu strategi mempunyai dasar-dasar atau skema untuk mencapai sasaran

21Bagian Proyek Pembinaan Pangan Halal Direktorat Jenderal Bimbingan Masyarakat Dan Penyelenggaraan Haji, Op. Cit., hlm.7.

${ }^{22}$ Ibid., hlm. 8.

${ }^{23}$ Lembaga Pengkajian Pangan Obat-Obatan dan Kosmetika Majelis Ulama Indonesia, Sertifikat Halal MUI, http://www.halalmui.org/mui14/ index.php/main/go_to_section/ 55/1360/page/1, diakses tanggal 14 September 2015.

24 Thobieb Al-Asyhar, Bahaya Makanan Haram bagi kesehatan Jasmani dan Kesucian rohani, (Jakarta: PT. Al-Mawardi Prima, 2003), hlm. 142-143. 
yang dituju. Jadi, pada dasarnya strategi merupakan alat untuk mencapai tujuan. ${ }^{25}$

Menurut Stephanie K. Marrus, strategi didefinisikan sebagai suatu proses penentuan rencana para pemimpin puncak yang berfokus pada tujuan jangka panjang organisasi, disertai penyusunan suatu cara atau upaya bagaimana agar tujuan tersebut dapat dicapai. ${ }^{26}$

Sedangkan strategi menurut Arifin adalah keseluruhan keputusan kondisional tentang tindakan yang akan dijalankan, guna mencapai tujuan. ${ }^{27}$ Definisi yang berprespektif organisasi sosial menjelaskan bahwa strategi merupakan segala rencana tindakan untuk mempengaruhi kebijakan, program, perilaku dan praktik publik. Untuk itu, sebagai suatu rencana di dalam strategi harus memuat ${ }^{28}: 1$ ) Tujuan, sasaran dan target yang jelas; 2) Serangkaian taktik dan kegiatan terkait; 3) Dilaksanakan dengan cara terorganisir dan sistematis.

\section{b. Pengertian Dakwah}

Dakwah menurut pengertian bahasa (etimologi) berasal dari bahasa arab: $d a^{\prime} a, y a d^{\prime} u, d a^{\prime} w a t a n$ yang berarti seruan, panggilan, undangan atau do'a. ${ }^{29}$ Sedangkan dakwah menurut istilah dalm kitab Al-Hidayah AlMursyidin, Ali Mahfuzh berpendapat bahwa dakwah adalah mendorong (memotivasi) umat manusia melakukan kebaikan dan mengikuti petunjuk serta memerintah mereka berbuat ma'ruf dan mencegah dari perbuatan munkar agar mereka memperoleh kebahagiaan dunia akhirat.30

Menurut Thoha Yahya, dakwah adalah mengajak manusia dengan cara yang bijaksana ke jalan yang sesuai dengan perintah Allah, demi kemaslahatan dan kebahagiaan manusia di dunia dan di akhirat. ${ }^{31}$

Dakwah dalam prosesnya akan melibatkan unsur-unsur dakwah yang terbentuk secara sistemik, artinya antara unsur yang satu dengan

25 Husein Umar, Strategic Management in Action, (Jakarta: PT Gramedia Pustaka Utama, 2001), hlm. 30.

26Ibid. hlm. 31

27 Anwar Arifin, Dakwah Kontemporer Sebuah Studi Komunikasi, (Yogyakarta: Graha Ilmu, 2011), hlm.227.

28 Thohir Yuli Kusmanto, Gerakan Dakwah di Kampus Riwayatmu Kini (Telaah Kritis Pola dan Strategi Gerakan Dakwah di Kam;pus Kota Semarang),(Semarang: Lembaga Penerbitan IAIN Walisongo Semarang, 2012), hlm. 40-41.

${ }^{29}$ Enjang \& Aliyudin, Dasar-Dasar Ilmu Dakwah Pendekatan Filosofis dan Praktis, (Widya Padjadjaran, 2009) hlm. 3.

30 Ibid, hlm. 6.

${ }^{31}$ Najamuddin, Metode Dakwah Menurut Al-Qur'an, ( Yogyakarta: Pustaka Insan Madani, 2008), hlm. 2. 
unsur yang lainnya saling berkaitan. Paling tidak ada enam unsur utama dalam proses dakwah yaitu: da'i (subyek dakwah), maudu' (materi dakwah), uslub (metode dakwah), wasilah (media dakwah), mad'u (obyek dakwah) dan tujuan dakwah. 32

\section{c. Pengertian Strategi Dakwah}

Strategi dakwah adalah proses penentuan cara dan upaya untuk menghadapi sasaran dakwah dalam situasi dan kondisi tertentu guna mencapai tujuan dakwah dengan memanfaatkan berbagai sumber daya. ${ }^{33}$ Dengan demikian strategi dakwah artinya metode, siasat, taktik atau manuver yang dipergunakan dalam aktivitas (kegiatan) dakwah. ${ }^{34}$

Dalam pandangan Muh. Ali Aziz, berdasarkan pada beberapa ayat $\mathrm{Al}$ Qur'an ( Q.S. Al Baqarah: 129 dan 151, Q.S. Ali Imran: 164, Q.S. Al Jum'ah: 2, Q.S. Al Mulk: 23) ada tiga strategi dakwah yang diajarkan Allah SWT. Adapun ketiga strategi dakwah tersebut meliputi35: pertama, strategi tilawah (membacakan ayat-ayat Allah SWT); dalam strategi ini mad'u diminta mendengarkan penjelasan da'i atau membaca sendiri pesan yang ditulis oleh da'i. Dalam hal ini tujuan dakwah akan tercapai melalui transfer pesan dakwah melalui lisan dan tulisan. Transfer pesan dakwah berlangsung pada wilayah kognitif (pemikiran), prosesnya sangat tergantung pada pemanfaatan indera pendengaran, penglihatan dan akal yang sehat. Kedua, strategi tazkiyah (menyucikan jiwa), merupakan strategi yang dijalankan dengan cara membersihkan jiwa manusia yang kotor oleh penyakit hati (sombong, ujub, serakah dan lain-lain). Ketiga, strategi ta'lim (mengajarkan Al-Quran dan Al-Hikmah, merupakan proses mentransformasikan pesan dakwah dengan mendalam, secara formal dan sistematis.

\section{d. Majelis Ulama Indonesia (MUI)}

MUI adalah Lembaga Swadaya Masyarakat yang mewadahi ulama, $z u$ 'ama, dan cendekiawan IslamdiIndonesiauntuk membimbing, membina dan mengayomi kaum muslimin di seluruh Indonesia. Majelis Ulama

32 Enjang \& Aliyudin, Dasar-Dasar Ilmu Dakwah Pendekatan Filosofis dan Praktis, (Widya Padjadjaran, 2009) hlm. 73.

${ }^{33}$ Awaludin Pimay, Paradigma Dakwah Humanis: Strategi dan Metode Dakwah Prof. KH. Saifuddin Zuhri, (Semarng: RaSail, 2005), hlm.50. hlm. 32 .

${ }^{34}$ Asmuni Syukir,Dasar-Dasar Strategi Dakwah Islam, (Surabaya: Al Ikhlas, 1983),

35 Thohir Yuli Kusmanto, Op.Cit., hlm. 47- 48. 
Indonesia berdiri pada tanggal 17Rajab1395Hijriah, bertepatan dengan tanggal26 Juli1975diJakarta. ${ }^{36}$

Beberapa fungsi Majelis Ulama Indonesia yaitu ${ }^{37}$ : 1) Sebagai wadah masyarakat para ulama, zuama dan cendekiawan muslim dalam mengayomi umat dan mengembangkan kehidupan yang islami; 2) Sebagai wadah silahturahmi para ulama, zuama dan cendekiawan muslim untuk mengembangkan dan mengamalkan ajaran Islam dan menggalang ukhuwah Islamiyah; 3) Sebagai wadah yang mewakili umat Islam dalam hubungan dan konsultasi antar umat beragama; 4) Sebagai pemberi fatwa kepada umat Islam dan Pemerintah, baik diminta maupun tidak diminta.

\section{Analisis Hasil Penelitian}

\section{Analisis Sertifikasi Halal Sebagai Strategi Dakwah Majelis Ulama Indonesia Jawa Tengah}

Mengacu pada teori yang ada maka strategi dakwah disini adalah segala rencana dakwah berupa tindakan untuk mempengaruhi kebijakan, program, perilaku dan praktik publik. Untuk itu, sebagai suatu rencana di dalam strategi harus memuat; tujuan, sasaran dan target yang jelas, dan serangkaian taktik dan kegiatan terkait, serta dilaksanakan dengan cara terorganisir dan sistematis. ${ }^{38}$

Lembaga pengkajian pangan, obat-obatan, dan kosmetika (LPPOM) MUI Provinsi Jawa Tengah merupakan salah satu lembaga publik dibawah naungan MUI yang mempunyai wewenang dalam mempengaruhi kebijakan, program, perilaku dan praktik publik dalam hal sertifikasi halal. Strategi dakwah LP POM MUI Provinsi Jateng dalam konteks mempengaruhi tersebut mempunyai tujuan untuk menciptakan Gerakan Masyarakat Sadar Halal "Gemar HALAL". Menciptakan gerakan masyarakat sadar halal merupakan bentuk grand action LP POM MUI Jateng dalam melakukan tindakan-tindakan publik untuk meningkatkan kesadaran masyarakat dalam mengkonsumsi produk-produk halal.

36 Majelis Ulama Indonesia, dalam http://id.wikipedia.org/wiki/ Majelis_Ulama_ Indone sia, diakses pada tanggal 6/04/2015.

${ }^{37}$ Pedoman Penyelenggaraan Organisasi Majelis Ulama Indonesia, (Sekretariat Majelis Ulama Indonesia Pusat, 2011), hlm. 19.

38 Thohir Yuli Kusmanto, Gerakan Dakwah di Kampus Riwayatmu Kini (Telaah Kritis Pola dan Strategi Gerakan Dakwah di Kam;pus Kota Semarang),(Semarang: Lembaga Penerbitan IAIN Walisongo Semarang, 2012), hlm. 40-41. 
Dalam rangka menciptakan "Gemar HALAL" melalui sertifikasi halal LPPOM MUI Jateng melakukan berbagai program yang dapat dijadikan sebagai ruang strategis untuk berdakwahnya, yaitu strategi pensertifikasian yang melalui berbagai program pelatihan, dan strategi sosialisasi dan promosi: 39

\section{a. Strategi Pensertifikasian}

\section{1) Pelatihan Sistem Jaminan Halal (SJH) 40}

Tujuan pelatihan SJH ini agar pimpinan dan auditor halal internal (AHI) pada perusahaan memahami $\mathrm{SJH}$ dan Objective-nya, serta dapat membuat manual SJH di perusahaan sendiri. Pelatihan ini penting kaitannya dengan tugas auditor halal internal (AHI) diantaranya membuat manual SJH, set-up system dan prosedur SJH, melakukan audit internal, alokasi sumber daya manusia dan sebagainya.

Pelatihan SJH ini diperuntukkan untuk perusahaan yang sudah mempunyai sertifikat halal atas produknya. Pelatihan SJH merupakan program tahunan LPPOM MUI Jateng. Pelatihan SJH Pertama kali dilaksanakan LPPOM MUI Jateng pada tanggal 3 Oktober 2012 yang dilaksanakan di Hotel Semesta Semarang. Pelatihan ini dimulai pada pukul 08.30 WIB yang dibuka oleh Direktur LP POM MUI Jawa Tengah, Prof Dr. H.M. Muchoyyar, HS.MA. kemudian dilanjutkan dengan presentasi para auditor LP POM MUI Jawa Tengah, yaitu Drs. Ir.H. Mochammad Iman, MBA, Sri Susilowati S.Si, M.Si., Apt. dan Nuryanto, S.Gz.

Materi presentasi meliputi 11 kriteria sebagai syarat dalam $\mathrm{SJH}$ meliputi Kebijakan Halal, Tim Manajemen Halal, Pelatihan dan Edukasi, Bahan, Produk, Fasilitas Produksi, Prosedur Tertulis untuk Aktivitas Kritis, Kemampuan telusur (traceability), Penanganan Produk yang tidak memenuhi kriteria, audit internal dan kaji ulang manajemen. Di dalam pelatihan ini juga dilakukan simulasi dan praktek dan pembuatan Manual SJH. Acara ini diakhiri dengan pemberian Sertifikat secara simbolik kepada

39 Wawancara dengan Drs. Ir. H. Mohammad Iman, MBA selaku Wakil Sekretaris pada tanggal jumat, 17 September 2015 pukul 10.20 WIB.

40 Sistem jaminan halal merupakan sistem manajemen terintregrasi yang disusun, diterapkan dan dipelihara untuk mengatur bahan, proses produksi, produk, sumber daya manusia dan prosedur dalam rangka menjaga kesinambungan proses produksi halal sesuai dengan persyaratan LPPOM MUI.bertujuan untuk memastikan kehalalan produk, menjaga konsistensi produk halal, menjaga kesadaran Internal dalam perusahaan, serta untuk menjaga adanya unsur ketidakhalalan pada produk yang telah tersertifikasi. 
peserta pelatihan SJH terbaik dan ditutup oleh Sekretaris LP POM MUI Jawa Tengah, Dr. H. Ahmad Izzudin, M.Ag.

Dalam pelatihan tersebut terdapat 31 peserta pimpinan perusahaan dan Auditor Halal Internal yang ikut serta. Perusahaan-perusahaan tersebut adalah Swiss bakery, PT. Pura Barutama, PT. Tripangan Maju Sejahtera, RM Candi Sari, PT Boga Makmur Gracia, CV. Toopfood Sarana Makmur, Waroeng Steak and Shake, PT. Lombok Gandaria, Toko Roti Virgin, PT Mitra Alvastar Buana, PT. Java Prima Abadi, PT. Charoen Pokpand, CV. Bianglala food, PT. Abon Juara, Roti Delizia Batang, PT. Indotirta jaya Abadi, PT. Kinosentra Industrindo, PT. Tirta Investama Klaten dan PT. Candra Buana Surya Semesta.

\section{2) Pelatihan CEROL SS23000}

Sertifikasi halal online tidak lain merupakan layanan untuk memindahkan layanan yang bersifat manual ke pelayanan secara online.Pelatihan ini dilaksanakan mulai tanggal 21 sampai 23 februari 2013. Pelatihan ini bertempat di aula MUI Jawa Tengah dengan narasumber Catur Prasetyo, S.TP dan Wahyu Lysdaputra dari LPPOM MUI pusat dan diikuti oleh seluruh pengurus internal LPPOM MUI Jawa Tengah dan Komisi Fatwa, serta beberapa undangan dari LPPOM MUI se-Indonesia.

Dalam pelatihan itu, peserta dibekali materi tentang user manual customer, auditing, sistem jaminan halal, keuangan, auditor, admin komisi fatwa, dan bagian sertifikasi.Dalam program ini, LPPOM MUI Jawa Tengah mencoba untuk memiliki domain sendiri pada rumah online LPPOM MUI Jateng. CEROL SS23000 merupakan bentuk pemanfaatan teknologi berbasis Technology Information yang bertujuan untuk lebih mempermudah pendaftaran sertifikat halal pada produk makanan atau kosmetik karena pengajuanya bisa dilakukan dengan sistem online. Sehingga pelaku usaha tidak lagi direpotkan dengan urusan administrasi. Disini pelaku usaha bisa mendaftarkan produk makanan ataupun kosmetik dengan jalur online. cukup mendaftar dan membayar biaya pendaftaran secara online, dan tim auditor akan datang ke tempat.

\section{b. Strategi Sosialisasi dan Promosi}

Strategi sosialisasi dan promosi yang dikelompokan sesuai target sasaranya yaitu:

1) Strategi kepada Produsen 
Strategi dipandang perlu untuk menumbuhkan kesadaran pelaku usaha mengenai pentingnya perlindungan konsumen sehingga tumbuh sikap yang jujur dan bertanggung jawab dalam berusaha selain itu juga meningkatkan kualitas barang dan/atau jasa yang menjamin kelangsungan usaha produksi, kesehatan, keamanan dan keselamatan konsumen. Strategi kepada produsen antara lain melalui:

a) Pemberian Sertifikasi Halal Gratis. ${ }^{41}$

Pemberian sertifikasi halal gratis merupakan bentuk kerja sama LPPOM MUI Jawa Tengah yang dijalin dengan BPOM RI (Badan Pengawas Obat dan Makanan Republik Indonesia).Pelaksanaannya di Aula Lt.2 Gedung MUI Jawa Tengah Komplek Masjid Baiturrahman Simpang Lima Semarang. Dalam acara ini hadir Dr. KH. Ahmad Darodji, M.S.I. selaku Ketua Umum MUI Provinsi Jawa Tengah dan Dr. KH. Ahmad Izzuddin, M.Ag. selaku Sekretaris LPPOM MUI Jawa Tengah Serta hadir pula Kepala Balai Besar Pengawas Obat dan Makanan di Semarang Drs. Agus Prabowo, MS, Apt. yang didampingi Dra. Aryanti, M.Si, Apt. dan Drs. Bambang Suryadi, MSi, Apt.

Penyerahan sertifikat halal kepada Industri Kecil Menengah (IKM) Pangan diserahkan langsung oleh Ketua Umum MUI Jawa Tengah Dr. KH. Ahmad Darodji, MSi, bersama Kepala BPOM, Drs. Agus Prabowo, MS, Apt. secara simbolik kepada IKM Wonosobo, IKM Kudus dan IKM Semarang sebagai perwakilan 46 IKM yang memperoleh sertifikat Halal tersebut, berasal dari 9 (sembilan) Kabupaten/Kota di Jawa Tengah, yaitu Kota Semarang 8, Kota Magelang 1, Kab. Semarang 4, Kab. Kendal 10, Kab. Kudus 4, Kab. Temanggung 5, Kab. Wonosobo 3, Kab. Purworejo 7 dan Kab. Magelang $4 .{ }^{42}$

Perusahaan/ikm yang sudah mendapat sertifikat halal untuk selalu melakukan sosialisasi produk-produknya berlabel halal sekaligus mempertahankan kualitas produk tersebut yang termasuk di dalamnya keamanan, mutu, gizi dan kehalalannya.

b) Seminar/Talkshow Halal

41 Pemberian sertifikasi halal gratis bertujuan untuk meningkatkan mutu dalam pengembangan kualitas perekonomian bangsa. Selain itu juga pemberian sertifikasi halal gratis akan menunujukkan semakin banyaknya produk yang sudah terjamin kehalalannya yang tersebar di Jawa Tengah.

42 http://www.pom.go.id/new/index.php/view/berita/7646/Penyerahan-SertifikatHalal-kepada-IKM-Program-Bantuan-Badan-POM-RI.html 
Seminar/talkshow halal bertujuan untuk memberikan edukasi kepada masyarakat mengenai konsep halal. Karena pada dasarnya dengan adanya kemajuan teknologi dalam proses produksi pangan, pengolahan produk menjadikan suatu makanan bahan yang digunakan halal bisa menjadi subhat atau haram karena terkontaminasi dengan barang yang haram. Dalam hal ini LPPOM MUI melakukan berbagai bentuk bekerja sama dengan universitas, Instansi dan media dalam menggelar seminar/ talkshow misal bekerja sama dengan Departemen Agama, BPOM dan perusahaan. Misalnya dalam seminar kepada asosiasi produsen tata boga yang sebagian belum paham/tahu mengenai konsep halal yang merupakan IKM dibawah binaan BPOM dan seminar terhadap WNA yang datang ke Indonesia yang ingin tahu mengenai halal ataupun sertifikasi halal.

\section{2) Strategi kepada Konsumen}

Strategi kepada konsumen bertujuan meningkatkan kesadaran, kemampuan dan kemandirian konsumen untuk melindungi diri dalam memilih produk halal. Strategi kepada konsumen antara lain melalui:

Pertama, berita dan informasi halal. Strategi melalui berita dan informasi halal merupakan aktivitas tulisan berupa penyampaian berita dan informasi mengenai program ataupun kegiatan yang telah dilaksanakan oleh LP POM MUI melalui : 1) Media visual yang dimaksud disini berbagai media massa tertulis seperti melalui,Surat kabar ${ }^{43}$, Booklet ${ }^{44}$, Artikel Halal 45 , Brosur, Pembuatan dan pemasangan spanduk di hari-hari Besar, serta Pencetakan dan penyebaran kalender LP POM MUI Jateng; 2) Media audiovisual melalui handphone ataupun internet yang sifatnya dapat diakses kapan saja.

Kedua, pesantren kilat ${ }^{46}$ merupakan program yang dilaksanakan setiap setahun sekali yang diadakan di sekolah-sekolah di kabupaten kota Semarang. Titik sasaran program ini yaitu tingkat SMP dan SMA.Program ini dilaksanakan dengan mendatangi sekolah-sekolah, sehingga LPPOM

43 Bentuk kerja sama dengan surat kabar misalnya dengan surat kabar; Suara Merdeka, Tribun Jateng, Radar Semarang, dan Suara NU.

${ }^{44}$ Booklet berbentuk buku yang berisi daftar nama-nama perusahaan yang telah tersertifikat halal beserta produk-produknya. Daftar Produk bersertifikat halal periode Maret 2014-2016 LPPOM MUI Jawa Tengah terdapat 584 produk yang telah terdaftar.

${ }^{45}$ Halal Artikel dimuat dalam website LPPOM MUI Jateng.

46Pesantren Kilat bertujuan memberikan pengetahuan sedini mungkin sehingga akan menimbulkan kesadaran anak untuk mengkonsumsi produk halal sehingga menimbulkan keterbiasaan dalam mengkonsumsi produk halal. Diharapkanpelajar lebih memahami akan konsep halal dan lebih selektif dalam mengkonsumsi produk pangan. 
MUI dalam pesantren kilat mengambil peran sebagai nara sumber yang menyampaikan materi mengenai konsep kehalalan makanan.

Ketiga, wisata halal (Halal Tour) ${ }^{47}$ merupakan Program yang memperkenal-kan kepada anak usia sekolah tentang proses pengolahan makanan dan minuman halal dan pengetahuan tentang kehalalan produk di perusahaan yang telah mendapat sertifikat halal.Pesertanya dari sekolahsekolah yang telah diundang untuk mengikuti program wisata halal. Seperti kunjungan ke Indofood, PT. Charoen Pokphand Indonesia. Dengan melihat proses dari produksinya, melihat proses pengolahanya sampai melihat produk hasil yang akan dipasarkan. Program wisata halal ini merupakan program yang dilaksanakan setiap satu tahun sekali.Wisata halal dalam kegiatannya terdapat Presentasi dari perusahanan mengenai produknya, Quis halal, dan tanya jawab. Wisata halal yang dilaksanakan pada tanggal 29 Maret 2014 diiikuti sebanyak 25 siswa siswi dari SMP Islam Sultan Agung.

Keempat, silahturahim; dalam silaturahim ini secara implisit mengajak tokoh-tokoh muslim untuk berpartisipasi karena merupakan tanggungjawab bersama dalam memasyarakatkan mengkonsumsi halal. Program silaturahmi bisa dibedakan menjadi dua kelompok yaitu: 1) Silaturahmi internal lembaga, dengan memanfaatkan momentum Halal bi halal pada hari Raya Idhul Fitri yang diselenggarakan untuk keluarga besar LPPOM MUI Jateng. Program ini diagendakan untuk segenap jajaran Pengurus dan Auditor LPPOM MUI Jawa Tengah. Dalam acara silaturahmi, Direktur LPPOM MUI Jawa Tengah, Prof. Dr. H. Muchoyyar HS, MA juga memberikan arahan kepada semua auditor bahwa sebagai seorang auditor, auditor harus mampu memberikan pelayanan terbaik pada perusahaan Direktur LPPOM MUI Jawa Tengah juga memberikan apresiasi kepada seluruh auditor yang selama ini telah bekerja keras dalam menjalankan tugasnya; 2) Silturahim eksternal lembaga, bentuk kegiatannya yaitu dengan berkunjung ke dinas-dinas di kabupaten kota Semarang, Perusahaan-perusahaan, BUMN,. Program ini dilaksanakan setiap selasa malam.Selain itu juga ada Silahturahim antar kyai di kabupaten kota Semarang yang agendanya berkumpul bersama, yang terdiri dari ketuaketua MUI daerah. Yang dalam forum silaturahmi tersebut para ulama saling bertukar pikiran satu sama lain salah satunya mengenai problematika kehalalan makanan sekarang masa ini.

${ }^{47}$ Wisata halal merupakan Program yang berbentuk kunjungan ke perusahaan dengan tujuan untuk memperkenalkan perusahaan-perusahaan yang telah bersertifikat halal. 
Kelima, olimpiade halal ${ }^{48}$ merupakan program yang dilaksanakan setiap tahun. Olimpiade ini diadakan untuk pelajar tingkat SMA tingkat nasional. Olimpiade digelar secara bertahap di beberapa wilayah. Di Jawa Tengah dilaksanakan di sekolah-sekolah Kota Semarang, Kudus, Pekalongan dan Jepara. Program ini diikuti sebanyak 611 siswa. Panitia pelaksana Olimpiade Halal Regional Jawa Tengah yaitu Bpk. Ahmad Susheri. Pelaksanaan olimpiade dilakukan di masing-masing sekolah secara online. Ujian dilaksanakan melalui program HaLO (Halal Learning Online) LPPOM MUI. Bentuk program ini siswa mengerjakan 50 butir soal pilihan ganda selama satu jam. Berbagai soal diberikan untuk mengetes pemahaman mereka, antara lain mengenai kehalalan dan kethayyiban, studi Islam, dan pengetahuan umum. Babak penyisihan dilaksanakan secara online, dan peserta dapat melakukan ujian di mana saja.

\section{Analisis Faktor Pendukung dan Penghambat}

Dalam melaksanakan programnya LPPOM MUI Jawa Tengah berusaha untuk meminimalisir kendala-kendala yang sekiranya menghambat proses pelaksanaan program yaitu dengan mengetahui strong point yang dimiliki oleh LPPOM MUI Jateng dalam pelaksanaan program. Adapun faktor pendukung dalam sertifikasi halal sebagai strategi dakwah Majelis Ulama Indonesia Jawa Tengah yaitu: 1) Tersedianya sarana dan prasarana yang memadai; 2) Terjalinya kerjasama dengan pihak internal dan eksternal lembaga; 3) Keikutsertaan ummat dalam program; 4) Anggota yang berkompeten dan berpengalaman sesuai bidangnya.

Sedangkan faktor penghambat di antaranya adalah: 1) Ada beberapa anggota yang mempunyai rangkap jabatan dalam satu lembaga; 2) Minimnya dana; 3) Kurang disiplinya anggota akan pekerjaan yang menjadi tanggung jawabnya.

\section{Simpulan dan Rekomendasi}

Kesimpulan yang diperoleh penulis dari penelitian ini menunjukkan bahwa MUI Jateng melalui LPPOM MUI sebagai lembaga yang berwenang dalam proses sertifikasi halal, melakukan berbagai program yang dijadikan sebagai ruang strategis untuk berdakwah.Dalamdakwah LPPOM MUI

48 untuk menumbuhkan dan meningkatkan kepedulian generasi muda terhadap produk halal dan menerapkan gaya hidup halal "Halal is My Life" dalam kehidupan seharihari. 
mengembangkan strategi yaitu strategi pensertifikasian yang melalui berbagai program pelatihan dan strategi melalui proses sosialisasi dan promosi. Kedua strategi tersebut dijalankan dalam program utama dari LPPOM MUI yaitu menciptakan gerakan masyarakat sadar halal atau yang disebut "Gemar HALAL". Strategi pensertifikasian yang melalui berbagai program Pelatihan dalam bentuk Pelatihan Sistem Jaminan Halal (SJH) yaitu program yang diperuntukan untuk perusahaan yang sudah mempunyai sertifikat halal yang bertujuan supaya perusahaan senantiasa menjaga konsistensi kehalalan produknya. Kedua Pelatihan CEROL SS23000 merupakan pelatihan yang diikuti oleh seluruh pengurus internal LPPOM MUI Jateng dan komisi fatwa, pelatihan ini bertujuan dalam rangka meningkatkan kualitas pelayanan terhadap konsumen yang mendaftarkan produknya untuk sertifikasi halal dengan secara online.

Strategi melalui sosialisasi \& promosi bertujuan untuk memberikan edukasi kepada masyarakat supaya mengerti dan memahami tentang pentingnya mengkonsumsi produk halal. Strategi sosialisasi dan promosi yang dikelompokkan sesuai target sasaranya yaitu: strategi kepada produsen dan strategi kepada konsumen. Strategi kepada produsen antara lain melalui: Pemberian Sertifikasi Halal Gratis merupakan program stimulus agar produsen selalu menjaga kualitas produknya dan terjamin kehalalanya. Dan Seminar / talkshow halal bertujuan untuk memberikan pemahaman kepada masyarakat menengah ke bawah mengenai konsep halal. Kedua strategi kepada konsumen melalui Berita \& Informasi halal yang meliputi berbagai media antara lain: surat kabar, booklet, artikel halal, brosur, pembuatan dan pemasangan spanduk di hari-hari besar, pencetakan dan penyebaran kalender LP POM MUI Jateng dan dengan menggunakan telepon serta internet. Pesantren Kilat bertujuan memberikan pengetahuan sedini mungkin mengenai konsep halal agar menimbulkan kesadaran dan keterbiasaan mengkonsumsi produk halal. Wisata Halal bertujuan untuk memperkenalkan perusahaan yang telah tersertifikat halal dengan bentuk kunjungan industri. Silahturahmi secara implisit mengajak tokoh-tokoh muslim untuk berpartisipasi karena merupakan tanggungjawab bersama dalam memasyarakatkan mengkonsumsi halal. Olimpiade Halal bertujuan untuk menumbuhkan dan meningkatkan kepedulian generasi muda terhadap produk halal dan menerapkan gaya hidup halal "Halal is My Life" dalam kehidupan sehari-hari.

Dalam pelaksanaan strategi dakwah Lembaga Pengkajian Pangan, Obat-obatan, dan Kosmetika Majelis Ulama Indonesia (LPPOM MUI) Jawa Tengah selalu dipengaruhi faktor pendukung dan faktor penghambat. Adapun faktor pendukung diantaranya tersedianya sarana dan prasarana 
yang memadai, terjalinnya kerjasama dengan pihak internal dan eksternal lembaga, keikutsertaan ummat dalam program, dan anggota yang berkompeten dan berpengalaman sesuai bidangnya. Sedangkan faktor penghambat diantaranya yaitu ada beberapa anggota yang mempunyai rangkap jabatan dalam satu lembaga, minimnya dana, dan kurang disiplinnya anggota akan pekerjaan yang menjadi tanggung jawabnya.

\section{DAFTAR PUSTAKA}

Al Asyhar, Thobieb, Bahaya Makanan Haram Bagi kesehatan Jasmani dan Kesucian Rohani, (Jakarta: PT Al-Mawardi Prima, 2003).

Apriyantono,Anton dan Nurbowo, Panduan Belanja dan Konsumsi Hala, (Jakarta: Khairul Bayan, 2003).

Arifin, Anwar, Dakwah Kontemporer Sebuah Studi Komunikasi, (Yogyakarta: Graha Ilmu, 2001).

Bagian Proyek Pembinaan Pangan Halal Direktorat Jenderal Bimbingan Masyarakat danPenyelenggaraan Haji, Buku Pedoman Strategi Kampanye Sosial Produk Halal, (Jakarta: Departemen Agama RI, 2003).

Booklet Lembaga Pengkajian Pangan Obat-obatan dan Makanan Majelis Ulama Indonesia Jawa Tengah, Daftar Produk Bersertifikat Halal Periode Maret 2014-2016.

Enjang dan Aliyudin, Dasar-Dasar Ilmu Dakwah Pendekatan Filosofis dan Praktis, (Bandung: Widya Padjadjaran, 2009).

Kusmanto, Thohir Yuli, Gerakan Dakwah di Kampus Riwayatmu Kini (Telaah Kritis Poladan Strategi Gerakan Dakwah di Kam;pus Kota Semarang. (Semarang: Lembaga Penerbitan IAIN Walisongo Semarang, 2012).

Lembaga Pengkajian Pangan Obat-Obatan dan Kosmetika Majelis Ulama Indonesia. Panduan Umum System Jaminan Halal LPPOM-MUI, (Jakarta: LPPOM MUI, 2008).

Lembaga Pengkajian Pangan Obat-Obatan dan Kosmetika Majelis Ulama Indonesia, Panduan Olimpiade Halal LPPOM MUI 2014 
Lembaga Pengkajian Pangan Obat-Obatan dan Kosmetika Majelis Ulama Indonesia. SertifikatHalalMUI. http://www.halalmui.org/muidiakses tanggal 14 September 2015.

Majelis Ulama Indonesia, dalam http://id.wikipedia.org/wiki/Majelis_ Ulama_Indonesia, diakses pada tanggal 6 April 2015.

Majelis Ulama Indonesia, Pedoman Penyelenggaraan Organisasi Majelis Ulama Indonesia, Edisi Revisi (Hasil Rakernas MUI Tahun 2011), (Jakarta: Sekretaria Majelis Ulama Indonesia Pusa, 2011).

Maulana, Achmad. dkk. , Kamus Ilmiah Populer: Lengkap dengan EYD dan Pembentukan Istilah serta Akronim Bahasa Indonesia, (Yogyakarta: Absolut, 2008).

Moleong, Lexy J, Metodologi Penelitian Kualitatif, (Bandung: PT Remaja Rosdakarya, 2013).

Najamuddin, Metode Dakwah Menurut Al-Qur'an, (Yogyakarta: Pustaka Insan Madani, 2008).

Pimay, Awaludin, Paradigma Dakwah Humanis: Strategi dan Metode Dakwah Prof. KH. Saifuddin Zuhri , (Semarang: RaSail, 2005).

Qardhawi, Yusuf, Halal Haram dalam Islam, (Solo: PT Era Adicitra Intermedia, 2011).

Sarosa, Samiaji, Penelitian Kualitatif: Dasar-Dasar, (Jakarta Barat: PT Indeks, 2012).

Sugiyono, Metodologi Penelitian Kualitatif Kuantitatif dan R\&D, (Bandung: Alfabeta, 2012).

Syukir, Asmuni, Dasar-Dasar Strategi Dakwah Islam, (Surabaya: Al Ikhlas, 1983).

Umar, Husein, Strategic Management in Action, (Jakarta: PT Gramedia Pustaka Utama, 2001).

UU Republik Indonesia Nomor 33 tahun 2014 tentang Jaminan Produk Halal pada pasal 3. 